\title{
Penyuluhan Bahaya Konsumsi Gula Berlebih pada Masyarakat Desa Sumberlerak Kabupaten Boyolali dengan Media Poster
}

\author{
Vradea Pramesta ${ }^{1}$, Alvira Intar Bella Cahya ${ }^{2}$, Ragil Saptaningtyas ${ }^{3}$, Ayu Rahmawati Sulistyaningtyas ${ }^{4}$, Stalis Norma \\ Ethica $^{5 \square}$ \\ ${ }^{1,2,3,4}$ Program Studi Diploma Teknologi Laboratorium Medik, Universitas Muhammadiyah Semarang, Indonesia \\ ${ }^{5}$ Program Pascasarjana Magister Ilmu Laboratorium Klinis, Universitas Muhammadiyah Semarang, Indonesia \\ norma@unimus.ac.id
}

\begin{abstract}
Obesity is a group of non-communicable diseases that has become a global health problem and has emerged as an epidemic in both developed and developing countries. Excessive sugar consumption is known to be a risk factor for obesity and can lead to Type 2 Diabetes Mellitus (T2DM) with a high mortality rate. An effort to reduce the habit of consuming excess sugar in an effort to prevent obesity according to government recommendations is counselling about the importance of limiting sugar consumption for health. This effort has also been carried out through the Community Health Development Program (PPKM) to the people of Sumberlerak Village, Boyolali Regency, Central Java, Indonesia, using posters as a medium of socialization. The aim is to improve the community in the village regarding the relationship of excessive sugar consumption with the risk and clinical symptoms of obesity and DM. A participatory approach in the form of counselling using studentmade posters has been carried out followed by evaluation in the form of filling out questionnaires before and after the counselling. Based on the results of the questionnaire analysis that has been carried out, PPKM in the form of counselling using posters as a communication medium can increase awareness about the dangers of excessive sugar consumption in the people of Sumberlerak Village, Boyolali Regency, Central Java.
\end{abstract}

Keywords: Sugar Consumption, Obesity, Counselling, Poster Media, Sumberlerak Village.

\begin{abstract}
Abstrak
Obesitas merupakan kelompok penyakit tidak menular yang menjadi masalah kesehatan dunia dan muncul sebagai epidemi baik di negara maju ataupun berkembang. Konsumsi gula yang berlebihan diketahui merupakan faktor risiko obesitas dan dapat berujung pada penyakit Diabetes Mellitus Type 2 (T2DM)_dengan angka mortalitas yang tinggi. Salah satu upaya untuk mengurangi kebiasaan mengkonsumsi gula berlebih dalam upaya mencegah obesitas sesuai anjuran pemerintah adalah penyuluhan tentang pentingnya pembatasan konsumsi gula bagi kesehatan. Upaya ini juga telah dilakukan melalui Program Pembangunan Kesehatan Masyarakat, PPKM) kepada masyarakat Desa Sumberlerak, Kabupaten Boyolali, Jawa Tengah, Indonesia, menggunakan poster sebagai media sosialisasi. Tujuannya adalah untuk meningkatkan pengetahuan masyarakat di desa tersebut terkait hubungan konsumsi gula berlebih dengan risiko dan gejala klinis dari obesitas dan DM. Pendekatan partisipatif berupa penyuluhan dengan media poster buatan mahasiswa telah dilakukan diikuti evaluasi berupa pengisian kuesioner sebelum dan sesudah penyuluhan. Berdasarkan hasil analisis kuesioner yang telah dilakukan, PPKM berupa penyuluhan menggunakan poster sebagai media komunikasi dapat meningkatkan kesadaran tentang bahaya konsumsi gula berlebih pada masyarakat Desa Sumberlerak, Kabupaten Boyolali Jawa Tengah.
\end{abstract}

Kata kunci: Konsumsi Gula, Obesitas, Penyuluhan, Media Poster, Desa Sumberlerak.

C 2021 Majalah Ilmiah UPI YPTK

\section{Pendahuluan}

Obesitas merupakan kelompok penyakit tidak menular yang telah menjadi masalah kesehatan dunia dan muncul sebagai epidemi baik di negara maju maupun berkembang [1]. Obesitas menjadi ancaman kesehatan yang serius bagi masyarakat karena perannya sebagai faktor risiko berbagai penyakit penyebab kematian utama termasuk Diabetes Mellitus (DM) [2]. Obesitas merupakan faktor lingkungan penting yang terlibat baik dalam etiopatogenesis maupun komplikasi pada kejadian DM yang paling umum di dunia, yaitu Diabetes Mellitus Type 2 (T2DM). T2DM termasuk penyakit dengan angka kematian yang tinggi. Peran obesitas pada perjalanan penyakit Diabetes Mellitus Type 1 (T1DM) juga telah dilaporkan [3]. Obesitas merupakan penyakit dengan banyak penyebab (multifaktorial) yang muncul karena adanya jaringan lemak berlebihan, atau kelainan metabolisme energi dan regulasi nafsu makan dalam tubuh. Secara fisiologis, obesitas dinyatakan sebagai akumulasi lemak yang abnormal dalam jaringan adiposa yang dapat mengganggu kesehatan [4].

Saat ini terdapat 422 juta orang di seluruh dunia yang menderita DM, sedangkan sebanyak 1,6 juta kematian 
per tahun disebabkan oleh penyakit ini. Jumlah kasus maupun prevalensi DM terus meningkat dalam beberapa dekade terakhir. Terdapat kesepakatan global untuk menghentikan peningkatan DM dan obesitas pada tahun 2025 [5]. Jumlah penderita DM di Indonesia juga terus meningkat [6]. Jumlah penderita DM di Indonesia mencapai 10,3 juta pada tahun 2017 sehingga menduduki peringkat ke-6 dunia [7].

Perilaku diet masyarakat sangat ditentukan oleh komunitas, keluarga dan faktor individu, berikut ketersediaan dan harga makanan. Kesukaan kita terhadap rasa manis telah dimulai sejak awal kehidupan dan menetap sepanjang masa kanak-kanak[8]. Hal ini menjelaskan mengapa sebagai pemberi rasa manis konsumsi gula di tengah masyarakat cukup tinggi. Namun demikian konsumsi gula yang berlebihan diketahui merupakan faktor risiko obesitas dan DM tipe 2 [9].

Di Indonesia, proporsi konsumsi makanan manis pada usia di atas tiga tahun dilaporkan sebesar $40,1 \%$. Sementara itu, rasio aktivitas fisik yang tidak memadai pada orang yang berusia di atas sepuluh tahun adalah 33,5\%. Tidaklah mengherankan hasil Survei Kesehatan Dasar Indonesia pada 2018, menunjukkan sebanyak $14,5 \%$ penduduk Indonesia yang berusia di atas 18 tahun mengalami obesitas [10]. Adanya resiko obesitas dan DM akibat kebiasaan mengkonsumsi gula berlebihan pada masyarakat di Indonesia perlu ditanggulangi. Pemerintah telah mendorong pembatasan kadar gula pada makanan melalui Peraturan Menteri Kesehatan No. 63 Tahun 2013 tentang Perubahan atas Permenkes Nomor 30 Tahun 2013 tentang pencatuman informasi gula pada produk pangan [11]. Salah satu upaya untuk mengoreksi kebiasaan mengkonsumsi gula berlebih sesuai anjuran pemerintah adalah penyuluhan tentang pentingnya pembatasan konsumsi gula bagi kesehatan. Melalui ceramah yang diakhiri dengan kegiatan evaluasi berupa pre-test dan post-test ataupun metode konseling peningkatan pengetahuan mengenai pembatasan konsumsi gula dapat dicapai [12-13].

Hasil survei awal menunjukkan bahwa masyarakat atau penduduk Desa Sumberlerak Kabupaten Boyolali sangat sering mengkonsumsi makanan dan minuman manis tanpa diimbangi dengan aktivitas fisik yang cukup. Selain itu anak-anak kecil di desa tersebut banyak yang lebih menyukai jajanan dengan komposisi kadar gula yang tinggi. Alasan masyarakat mengkonsumsi gula dengan berlebih adalah karena di masa pandemi. Corona Virus Disease 2019 (Covid-19) banyak aktivitas yang dilakukan di dalam rumah sehingga muncul gairah atau rasa ingin terus makan tanpa mempedulikan kandungan gula dalam makanan tersebut. Kondisi ini tentunya beresiko bagi kesehatan penduduk karena kelebihan konsumsi gula dapat menyebabkan obesitas ataupun penyakit DM.
Artikel ini melaporkan pelaksanaan program PPKM (Program Pembangunan Kesehatan Masyarakat) berupa penyuluhan "Bahaya Konsumsi Gula Berlebih" dengan media poster hasil karya mahasiswa. Program PPKM adalah program pengabdian masyarakat terpadu yang melibatkan dosen dan mahasiswa Program Studi Diploma 3 Teknologi Laboratorium Medik (D3 TLM), Universitas Muhammadiyah Semarang [14-16]. Program ini secara umum bertujuan untuk menerapkan ilmu pengetahun dan teknologi yang dimiliki mahasiswa dan dosen agar bermanfaat bagi peningkatan kualitas kesehatan masyarakat [15].

\section{Metode Pengabdian}

Metode pengabdian yang dilakukan meliputi 3 tahapan utama mengacu pada metode sebelumnya [17]:

\subsection{Tahap persiapan}

Tahap persiapan kegiatan PPKM meliputi pelaksanaan survei lokasi yaitu Desa Sumberlerak Kabupaten Boyolali.

2.2. Tahap pelaksanaan meliputi:

a. Mengamati kebiasaan pola makan penduduk di lokasi pengabdian yaitu Desa Sumberlerak Kabupaten Boyolali.

b. Penetapan pelaksanaan kegiatan utama yaitu penyuluhan pada hari Sabtu 26 Desember 2020.

c. Pembuatan materi sosialisasi dalam bentuk poster bertema bahaya konsumsi gula berlebih dengan bahasa dan gambar yang mudah dimengerti oleh masyarakat

d. Pengisian daftar hadir dilakukan pada hari pelaksanaan diikuti dengan mengisi kuesioner pretest terlebih dahulu sebelum memaparkan materi. Tujuan pemberian kuesioner pre-test adalah untuk mengetahui tingkat pengetahuan awal masyarakat mengenai bahaya bahaya konsumsi gula berlebih sebelum materi penyuluhan diberikan [18].

e. Pemberian poster kepada peserta dilakukan pada saat pemaparan materi mengenai pentingnya komsumsi gula, batasan konsumsi gula, bahaya bagi kesehatan apabila mengkonsumsi gula berlebihan. Pada poster dan materi pemaparan diberikan tips untuk membatasi konsumsi gula dalam pola makan sehari-hari.

f. Setelah pemaparan, aktivitas dilanjutkan dengan sesi tanya jawab dan pengisian kuesioner kembali untuk dapat menilai kepahaman masyarakat mengenai materi yang disosialisasikan.

g. Acara sosialisasi diakhiri dengan sesi foto bersama sebagai bukti pelaksanaan program PPKM.

2.3. Tahap evaluasi 
Tahap evalusai dilakukan dengan mengolah data hasil kuesioner. Selain itu evaluasi juga dilakukan dengan meminta tanggapan dan respon masyarakat desa yang menjadi peserta penyuluhan mengenai acara sosialisasi yang diberikan.

\section{Hasil dan Pembahasan}

Program Pembangunan Kesehatan Masyarakat (PPKM) kepada masyarakat Desa Sumberlerak, Kabupaten Boyolali, Jawa Tengah, Indonesia menggunakan poster sebagai media sosialisasi telah dilakukan dalam kurun waktu 1-30 Desember 2020. Program penyuluhan yang dilakukan bertema "Bahaya Konsumsi Gula Berlebih". Tim pengabdi terdiri dari mahasiswa sebanyak 2 orang bersama seorang dosen pengarah, ketiganya dari Program Studi D3 Teknologi Laboratorium Medik (D3 TLM) Universitas Muhammadiyah Semarang.

Tahap awal berupa survei lokasi, perencanaan, perijinan, pembuatan poster sebagai media penyuluhan, serta pembuatan kuesioner telah dilakukan. Desain poster dan kuesioner yang telah dibuat oleh tim untuk digunakan dalam program penyuluhan ditunjukkan masing-masing pada Gambar 1 dan 2. Acara inti berupa penyuluhan yang dilaksanakan pada hari Sabtu, 26 Desember 2020 di Desa Sumberlerak Kabupaten Boyolali, Jawa Tengah yang dihadiri 9 orang peserta dari mitra sasaran (Gambar 3). Kegiatan penyuluhan diawali dengan pengisian kuesioner pre-test, pembagian poster yang dicetak dalam bentuk leaflet,

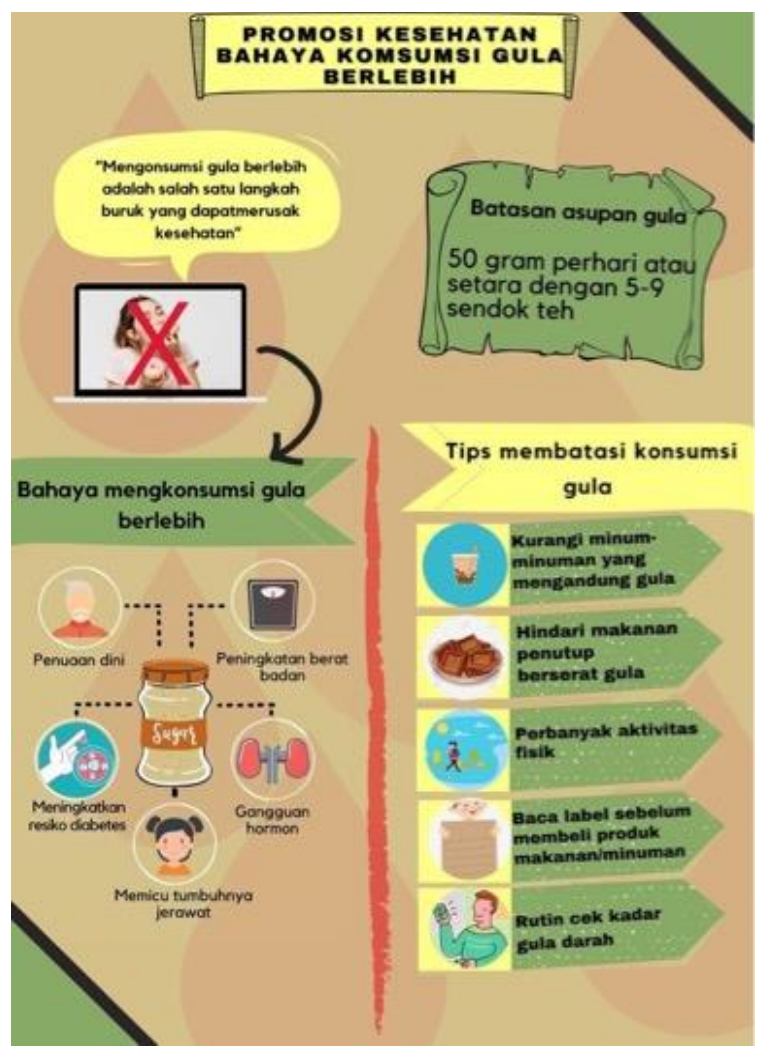

Gambar 1. Desain poster hasil karya tim pengabdi yang digunakan sebagai media penyuluhan.

KUESIONER PROMOSI KESEHATAN
Prodi D3 Analis Kesehatan Universitas Muhammadiyah Semarang
"Sosialisasi Bahaya Konsumsi Gula Berlebih"
Setelah Penyuluhan
1. Apakah gula mempunyai peran penting dalam tubuh?
c. Ya.
d. Tidak
2. Berapa batasan konsumsi gula per harinya?
c. 50 gram atau setara dengan 5-9 sendok teh
d. 35 gram atau setara dengan $4-6$ sendok the
3. Selain diabetes, konsumsi gula berlebihan menyebabkan obesitas dan timbul
jerawat
c. Ya
d. Tidak
4. Dalam studi kasus dimasyarakat laki - laki lebih rentan terkena resiko diabetes
c. Ya
d. Tidak
d. Perbanyak akitivitas fisik

Gambar 2. Desain kuesioner program penyuluhan.

penempelan poster yang dilanjutkan dengan pemaparan materi. Acara inti penyuluhan diakhiri dengan tanya jawab dan pengisian kuesioner post-test.

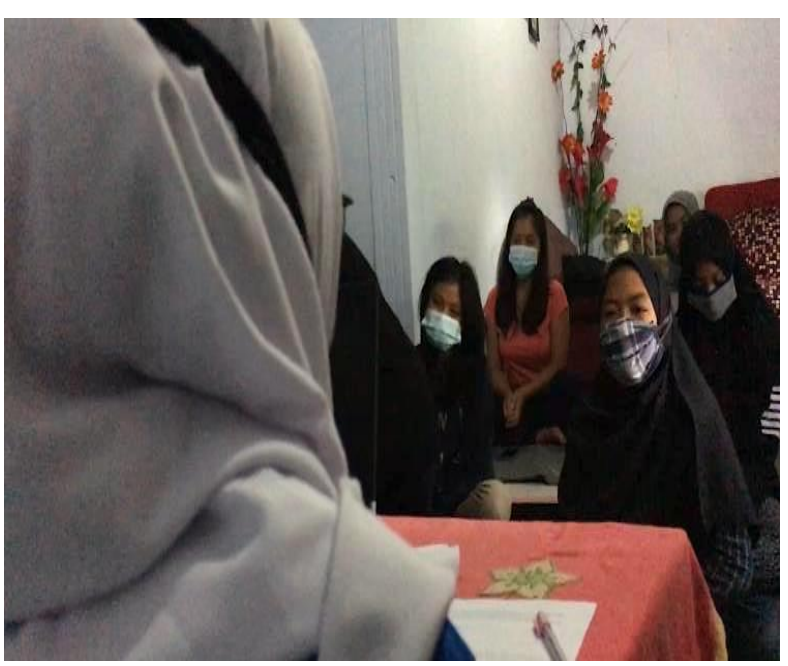

Gambar 3. Foto dokumentasi kegiatan.

Materi yang diberikan dalam penyuluhan tersebut meliputi pengertian singkat mengenai gula, bahaya konsumsi gula berlebih dan tips atau cara membatasi konsumsi konsumsi gula. Kuesioner pre-test dan posttest yang diberikan terdiri dari pertanyaan - pertanyaan mengenai gula sederhana, makanan yang mengandung 
gula sederhana, dan makanan sehat seimbang. Leaflet yang diberikan juga berisikan materi yang sama dengan materi yang dijelaskan pada saat pemaparan materi. Gambar 4 menunjukkan poster berisi materi penyuluhan dalam bentuk leaflet yang telah dibagikan kepada seluruh peserta penyuluhan.

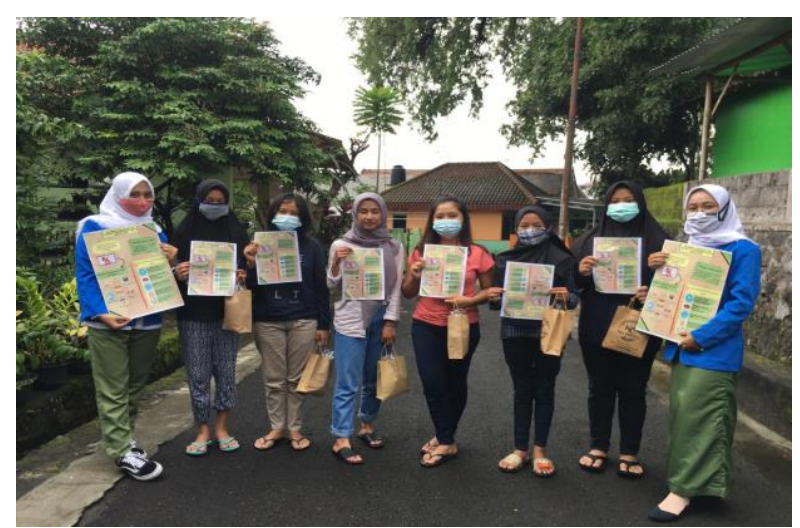

Gambar 4. Foto dokumentasi poster materi penyuluhan

Berdasarkan hasi evaluasi, kegiatan penyuluhan yang dilakukan berlangsung cukup baik dibuktikan dengan hadirnya tamu undangan tepat waktu. Selain itu, pada sesi tanya jawab juga terdapat beberapa respon dari peserta dengan menanyakan materi yang dianggapnya kurang jelas. Hal ini merupakan indikasi yang positif adanya perhatian dan ketertarikan masyakarat desa terhadap materi penyuluhan yang dipaparkan.

Target kegiatan pengabdian masyarakat yang dilakukan oleh tim PPKM dari Program Studi D3 TLM Universitas Muhammadiyah Semarang ini adalah perubahan perilaku (sosial) masyarakat agar membatasi konsumsi gula dalam pola makan sehari-hari. Perubahan perilaku yang dimaksud hanya dapat terjadi apabila pengetahuan mereka tentang bahaya konsumsi gula berlebihan terhadap kesehatan, khususnya terkait resiko obesitas dan T2DM, dapat ditingkatkan. Indikasi adanya perubahan pengetahuan ini berusaha diukur melalui kuesioner yang diberikan dalam bentuk pretest dan post-test yang diadopsi dari beberapa kegiatan PPKM sebelumnya [13-16].

Grafik data yang berisi nilai kuesioner yang dapat dicapai peserta pada pre-dan post-test yang diberikan dalam penyuluhan dapat dilihat pada Gambar 5.

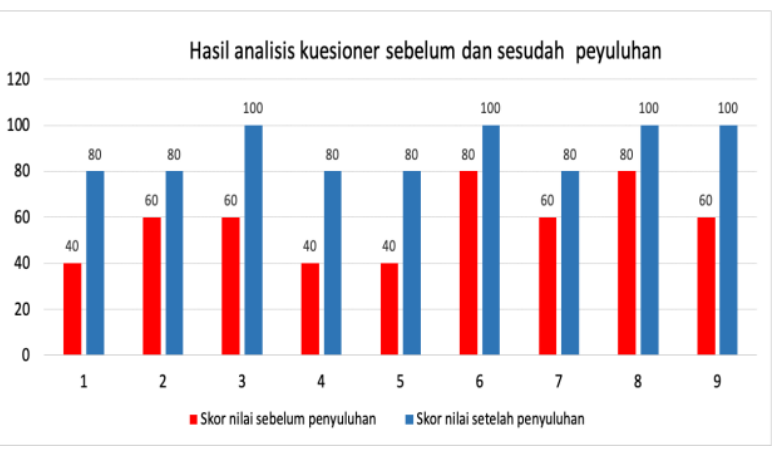

Gambar 5. Grafik hasil analisis kuesioner

Tabel 1. Output analisis statistik hasil kuesioner berdasarkan nilai pre-test dan post-test

\begin{tabular}{lccc}
\hline Product & Responden & Hasil pre-test & Hasil post-test \\
\hline N Valid & 9 & 9 & 9 \\
Missing & 0 & 0 & 0 \\
Rerata & & 58 & 89 \\
Standar deviasi & & 12 & 11 \\
Minimum & & 40 & 80 \\
Maksimum & & 80 & 100 \\
\hline
\end{tabular}

Hasil analisis statistik terhadap data pada Gambar 5 ditunjukkan pada Tabel 1. Tabel menunjukkan adanya peningkatan rerata nilai pre-test dan post-test seluruh peserta dari 58 menjadi 89. Hal ini berarti terdapat peningkatan pengetahuan peserta kegiatan tentang konsumsi gula sederhana pada masyarakat Desa Sumberlerak Kabupaten Boyolali setelah diberikan penyuluhan oleh tim PPKM.

Gambar 5 menunjukkan perbandingan antara jawaban kuesioner peserta sebelum dan sesudah penyuluhan yang berasal dari 9 peserta. Sebelum penyuluhan (pretest), terdapat 3 peserta dengan nilai terendah yaitu 40 dari nilai maksimal 100. Setelah kegiatan penyuluhan, nilai ketiganya meningkat menjadi 80 yang artinya pemahaman mereka meningkat sehingga di akhir kegiatan ketiga peserta ini memiliki pemahaman $40 \%$ lebih baik dari sebelumnya.

Secara keseluruhan, setelah penyuluhan dilakukan, nilai rerata peserta meningkat dari menjadi 58 menjadi 89 ada. Seluruh peserta yang mengikuti kegiatan dapat memperoleh manfaat dengan memperbaiki jawaban mereka dengan mengikuti kegiatan penyuluhan yang diberikan. Sebelumnya tidak ada peserta yang memberikan $100 \%$ jawaban benar, namun setelah acara penyuluhan dengan poster diberikan, 4 dari 9 peserta (44\%) mampu mendapatkan nilai maksimal 100. Dapat dikatakan bahwa masyarakat Desa Sumberlerak kabupaten Boyolali yang pada awalnya kurang memahami bahaya konsumsi gula berlebih, yang membawa risiko timbulnya obesitas ataupun DM, menjadi lebih memahami hal tersebut setelah diberikan penyuluhan. Dengan kata lain, setelah mendapat penyuluhan, pemahaman peserta akan bahaya konsumsi gula berlebihan terhadap kesehatan, khususnya terkait resiko obesitas dan DM, pihak yang 
rentan terhadap penyakit DM, kesadaran untuk membatasi konsumsi gula dalam makanan sehari-hari dapat ditingkatkan. Selain itu juga terbukti bahwa penggunaan poster sangat mendukung kegiatan penyuluhan yang dilakukan. Hal ini sejalan dengan berbagai penelitian yang telah dilaporkan sebelumnya, yang menyatakan bahwa bahwa penggunaan media poster sangat bermanfaat dalam mendukung kegiatan penyuluhan Kesehatan [19-20]

Berdasarkan hasil evaluasi kegiatan baik dari hasil analisis kuesioner peserta maupun respon peserta terhadap kegiatan yang dilakukan, pemahaman penduduk Desa Sumberlerak Kabupaten Boyolali yang mengikuti kegiatan terkait pentingnya pembatasan konsumsi gula berlebih bagi kesehatan telah meningkat. Dalam jangka panjang, pemahaman ini diharapkan dapat menjadi titik balik peningkatan pengetahuan penduduk akan bahaya obesitas dengan terus mencari cara-cara baru dalam mencegah masalah kesehatan tersebut.

\section{Kesimpulan}

Kegiatan penyuluhan "Bahaya Konsumsi Gula Berlebih" sebagai bagian dari program PPKM Universitas Muhammadiyah Semarang bagi masyarakat Desa Sumberlerak Kabupaten Boyolali Provinsi Jawa Tengah telah berhasil dilaksanakan. Hasil evaluasi menunjukkan bahwa penggunaan media poster bermanfaat dalam meningkatkan pemahaman peserta yang merupakan anggota masyarakat Desa Sumberlerak dalam kegiatan penyuluhan kesehatan.

\section{Ucapan Terimakasih}

Kami juga mengucapkan terima kasih kepada Program Studi Diploma Teknologi Laboratorium Medik (TLM) Universitas Muhammadiyah Semarang yang telah mensponsori program PPKM sehingga pelaksanaan kegiatan pengabdian kepada masyarakat ini dapat dijalankan dengan baik.

\section{Daftar Rujukan}

[1] World Health Organization. (2018). Noncommunicable diseases country profiles https://apps.who.int/iris/handle/10665/274512

2018.

[2] Alipour, F. G., Ashoori, M. R., Pilehvar-Soltanahmadi, Y., \& Zarghami, N. (2017). An overview on biological functions and emerging therapeutic roles of apelin in diabetes mellitus. Diabetes \& Metabolic Syndrome: Clinical Research \& Reviews, 11, S919-S923. https://doi.org/10.1016/j.dsx.2017.07.016

[3] Chobot, A., Górowska-Kowolik, K., Sokołowska, M., \& JaroszChobot, P. (2018). Obesity and diabetes - not only a simple link between two epidemics. Diabetes/metabolism research and reviews, 34(7), e3042. https://doi.org/10.1002/dmrr.3042

[4] Diels, S., Vanden Berghe, W., \& Van Hul, W. (2020). Insights into the multifactorial causation of obesity by integrated genetic and epigenetic analysis. Obesity Reviews, 21(7), e13019. https://doi.org/10.1111/obr.13019
[5] World Health Organization (WHO). Diabetes https://www.who.int/health-topics/diabetes\#tab=tab_1

[6] Amarta, O. R., Chalidyanto, D., \& Laksono, A. D. (2021). Ecological Analysis of Diabetes Mellitus in Indonesia. Indian Journal of Forensic Medicine \& Toxicology, 15(3), 3897. https://doi.org/10.37506/ijfmt.v15i3.15905

[7] Atlas, I. D. (2019). 2019. International Diabetes Federation; 2019. Online version of IDF Diabetes Atlas: www.diabetesatlas.org

[8] Paglia, L. (2019). The sweet danger of added sugars. Eur. J. Paediatr. Dent, 20, https://doi.org/10.23804/ejpd.2019.20.02.01

[9] Johnson, R. J., Sánchez-Lozada, L. G., Andrews, P., \& Lanaspa, M. A. (2017). Perspective: a historical and scientific perspective of sugar and its relation with obesity and diabetes. Advances in Nutrition, 8(3), 412-422. https://doi.org/10.3945/an.116.014654

[10]National Institute of Health Research and Development of The Indonesia Ministry of Health. The 2018 Indonesia Basic Health Survey (Riskesdas): National Report [Internet]. Jakarta; 2019. Available

from: http://labdata.litbang.kemkes.go.id/images/download/laporan/R KD/2018/Laporan_Nasional_RKD2018_FINAL.pdf

[11] Amiroh, A., Dwiyana, P., \& Mardiyah, S. (2021). Edukasi Gizi Pola Konsumsi Rendah Gula, Garam, Lemak (GGL) pada Remaja. Community Empowerment, 6(4), 595-601. https://doi.org/10.31603/ce.4600

[12] Ismawanti, Z., Safitri, W., \& Andarbeni, D. P. (2020). Pembatasan Konsumsi Gula, Garam dan Lemak Melalui Cakram Edukasi Gizi Seimbang pada Penderita Diabetes Mellitus Tipe 2. Jurnal Pengabdian Kepada Masyarakat Ungu (ABDI Ke Ungu), 2(2),

63-67. http://journal.aisyahuniversity.ac.id/index.php/Abdi/article/view/ LIMITATIONzuhria

[13] Idealistina, L., Anggraeni, N., \& Khairiyah, R. (2021). Upaya Peningkatan Pengetahuan Masyarakat Terkait Pembatasan Konsumsi Gula, Garam, dan Lemak Melalui Kegiatan Konseling Gizi di Wilayah Puskesmas Marga Jaya. Jurnal Antara Abdimas Kebidanan, 4(1), 1-8. https://doi.org/10.37063/pengmas.v4i1.546

[14] Adhestigita, A., Pratama, R. G., Afifah, N., Febiana, T., Rahayu, S., Sulistyaningtyas, A. R., ... \& Ethica, S. N. (2019). Kegiatan Pengabdian Masyarakat sebagai Upaya Mendapatkan Gambaran Penderita Penyakit Tuberculosis Melalui Program Praktik Pembangunan Kesehatan Masyarakat (PPKM) di Puskesmas Lamper Tengah Semarang Tahun 2018-2019. In Prosiding Seminar Nasional Mahasiswa Unimus (Vol. 2). https://prosiding.unimus.ac.id/index.php/mahasiswa/article/view/ 480

[15] Indriatiningsih, W., Nugraha, W. A., Putri, S. M., Sa'adah, A., Sulistyaningtyas, A. R., \& Ethica, S. N. (2019). Praktik Pembangunan Kesehatan Masyarakat (PPKM) dalam Upaya Pencegahan Penyakit Kardiovaskuler di Desa Ngablak Kidul, Pedurungan, Semarang. In Prosiding Seminar Nasional Mahasiswa Unimus (Vol. 2 ). https://prosiding.unimus.ac.id/index.php/mahasiswa/article/view/ 433

[16] Kurniawati, D. N., Dewi, T. M. K., Febiana, T., Sulistyowati, S., Sulistyaningtyas, A. R., Darmawati, S., \& Ethica, S. N. (2019). Pelaksanaan Pengabdian Masyarakat dalam Upaya Monitoring Penyakit Tuberculosis Melalui Praktik Pembangunan Kesehatan Masyarakat (PPKM) di Puskesmas Lamper Tengah Semarang Tahun 2019. In Prosiding Seminar Nasional Mahasiswa Unimus (Vol. https://prosiding.unimus.ac.id/index.php/mahasiswa/article/view/ 441 
[17] Saputra, A. M., \& Ethica, S. N. (2021). Socialization of The Importance of Early Diabetes Mellitus Prevention using Poster Media for Young Tenants of Boarding House in Tembalang Sub-District, Semarang Jurnal Pengabdian Pada Masyarakat, 6(3). https://doi.org/10.30653/002.202163.760

[18]Ethica, S. N., Sulistyaningtyas, A. R., Ernanto, A. R., Afriansyah, M. A., \& Mukaromah, A. H. (2020). Socialization of Lupus Disease Awareness for Housewife Group of Genting Village, Ambarawa, Central Java. Jurnal Pengabdian Pada Masyarakat, $5(4)$,

906-916. https://doi.org/10.30653/002.202054.444
[19] Yulianis, Y., Fauziah, A. U., \& Kusumawati, D. (2020). Informasi Kesehatan melalui Penyuluhan, Poster dan Leaflet di Dusun Talang Parit Desa Kemingking Dalam Kecamatan Taman Rajo Provinsi Jambi. Jurnal Abdimas Kesehatan (JAK), 2(2), 157-162. http://dx.doi.org/10.36565/jak.v2i2.118

[20] Ratnawati, R., Andini, A. N., \& Indrasena, B. (2021). Penyuluhan Tentang Covid-19 Dengan Pemanfaatan Media Poster Pada Masyarakat Di Desa Mangunrejo. Jurnal Pengabdian Dharma Bakti, 1(1), 56-61. https://doi.org/10.35842/jpdb.v1i1.140 